\title{
Work from Home: Measuring Satisfaction between Work-Life Balance and Work Stress during the COVID-19 Pandemic in Indonesia
}

\author{
Dodi Wirawan Irawanto ${ }^{1, *}$, Khusnul Rofida Novianti ${ }^{2}$ (D) and Kenny $\operatorname{Roz}^{2}$ (D) \\ 1 Management Department, Faculty of Economics and Business, Brawijaya University, Malang 65145, Indonesia \\ 2 Management Department, Faculty of Economics and Business, University of Muhammadiyah Malang, \\ Malang 65144, Indonesia; khusnulrofida@umm.ac.id (K.R.N.); firdauskenny@umm.ac.id (K.R.) \\ * Correspondence: dodi.wi@ub.ac.id
}

Citation: Irawanto, Dodi Wirawan, Khusnul Rofida Novianti, and Kenny Roz. 2021. Work from Home: Measuring Satisfaction between Work-Life Balance and Work Stress during the COVID-19 Pandemic in Indonesia. Economies 9: 96. https:// doi.org/10.3390/economies9030096

Academic Editor: Edward Hoang

Received: 18 May 2021

Accepted: 18 June 2021

Published: 25 June 2021

Publisher's Note: MDPI stays neutral with regard to jurisdictional claims in published maps and institutional affiliations.

Copyright: (c) 2021 by the authors. Licensee MDPI, Basel, Switzerland. This article is an open access article distributed under the terms and conditions of the Creative Commons Attribution (CC BY) license (https:// creativecommons.org/licenses/by/ $4.0 /)$.

\begin{abstract}
Coronavirus (COVID-19), which hit in early 2020, changed the way people live and work, and affected industries and organizations all over the world. Many organizations have begun to deliver a new way of working to adapt to these shifts effectively using teleworking or a work from home policy. The purpose of this study was to fill the gaps by investigating several potential predictors of job satisfaction during working from home from the impact of COVID-19 such as work-life balance and work stress. Using a quantitative approach, 472 workers who were forced to work from home all over Indonesia participated, and the responses were analyzed using Smart-PLS software. The study revealed that working from home, work-life balance, and work stress have a significant effect, both directly and indirectly, on job satisfaction. Working from home as a new pace of work can sustain job satisfaction as the current working atmosphere for Indonesian workers. In response to the collectivist setting, working from home can be a positive sign that needs to be paid attention to for the organization.
\end{abstract}

Keywords: work from home; job satisfaction; work stress; work-life balance; teleworking; COVID-19

\section{Introduction}

In early 2020, the impact of coronavirus (COVID-19) spread that affected all over the world created economic and social shock, which specifically in the organization world will likely reshape the way people live and work and the way in which industries and organizations operate. One of the most observable changes as a result of the COVID19 pandemic is teleworking, telecommuting, or the working from home policy across occupations (Kramer and Kramer 2020). Teleworking was suggested by the World Health Organization to be implemented by governments and organizations around the world as a new work innovation to prevent the spread of the virus as well as a solution so that work can be performed as usual. This refers to a flexible working approach not constrained by time, place, type of technical communication, and the use of information. Working from home was inevitable, but the pandemic turned it into a compulsion. It is speculated that even after the pandemic has ended, this current global job norm will continue. Not only the way in which organizations work, but also the relationship between workers and employers has been deeply impacted by this transition. Teleworking became widespread in the early 1990s as a result of organizations' demand for remote working settings (Di Martino and Wirth 1990; Neirotti et al. 2013). Teleworking's efficacy was also boosted by the demand for work-life balance as a result of the growing number of single parents in today's world (Baruch 2000; Marx et al. 2021). Bentley et al. (2016) responded to the rapid development of ICT and the pandemic crisis and suggested that teleworking should be reintroduced. Many organizations have started to offer a new way of working (Fedáková and Ištoňová 2017) to respond to these innovations effectively, both in terms of the work and personal 
life of the workers. The possibility of working from home has been considered as the means of increasing an individual's work-life balance because work from home provides an opportunity to take care of family members (Ammons and Markham 2004; Johnson et al. 2007). The working from home policy has some potential advantages and risks at the same time that must be considered. Working from home is effective to improve the quality of life (Azarbouyeh and Jalali Naini 2014), employee happiness, work satisfaction (Kazekami 2020), and openness to creativity that will lead to innovation (Ellis and Webster 1998).

Research to date has shown that in many countries around the world, teleworking is rising in popularity, with the number of teleworkers rising every year, being expected to double every year (Raišiene et al. 2020). Teleworking increases job performance, lessens work-family imbalance, reduces stress levels, and lessens turnover intentions (Contreras et al. 2020; Kossek et al. 2006; Fonner and Roloff 2010; Coenen and Kok 2014; Anderson et al. 2015). However, this benefit can be proven if employees can obtain managerial support, peer support, and technological support. Working from home support helps to reduce any potential negative impacts arising from social isolation and mitigates workfamily and work-life balance conflict (Contreras et al. 2020). Working from home also provides more flexibility for workers to deal with family matters because they can work wherever and anywhere, thereby strengthening the family environment and allowing them to harmonize the autonomy of time management and their personal and job duties. Moreover, teleworking lets workers build their working rhythm and remove distractions from other employees. The lack of an immediate overseer and less formal supervisor in the workplace decreases employee stress at work. Moreover, it eliminates the individual and organizational burden of absenteeism because it enables employees to fulfill their job obligations even in times of difficulty reaching the workplace and accomplishing their responsibility. Indeed, these benefits lead to greater loyalty and commitment to the organization, job satisfaction, work-life balance, and well-being.

The side effects and risks that need to be considered when introducing telecommuting work such as social isolation can be a serious problem that causes workers to be detached and leads to reduced motivation and performance (Martin and MacDonnell 2012). Work from home often makes workers have no clear boundaries between work and personal life so that it impacts work overload, which will increase stress (Liu and Lo 2018) and anxiety, as well as affecting their job satisfaction. The purpose of this study is to fill the gaps in the literature by investigating several potential predictors of job satisfaction during working from home as per the impact of COVID-19. Therefore, the aims of this study were first to examine the effects of working from home, work-life balance, and work stress on job satisfaction, and second to investigate whether work-life balance and work stress play a moderating role in the relationship between work from home and job satisfaction in the context of Indonesian workers. This study provides a theoretical and practical contribution. For theoretical contribution, this study provides a model proposed to explain the relationship between working from home, work-life balance, work stress, and job satisfaction. For practical contributions, this research suggests the importance of work-life balance and how to maintain work stress during the work from home policy implemented in the first year of COVID-19 hitting the world, specifically in the Indonesian context.

\section{Literature Review}

\subsection{Working from Home}

The concept of working from home was first put forward in the 1970s as telework or telecommuting, a new alternative in performing work from different locations (office, home, or another place) using technological assistance (van Meel 2011) that completely replaced work-related travel (Nilles 1997). Teleworking is very popular in the European context in terms of aspects related to work-life balance, especially after the European Framework Agreement on Telework, signed in 2002, which states that teleworking is defined as a type of activity or execution of work that utilizes information technology, 
wherein work can be carried out regularly (Wojčák and Baráth 2017). Some experts suggest that the concept of telework is the main idea behind working from home (Baruch 2001; Chung 2018). Teleworking has always been discussed because of the blurring boundaries of not being physically present at a job concerning non-work and work, personal and social consequences, and the risks and benefits of flexible working hours. There are some advantages of doing telework or work from home, namely, time planning skills, the possibility to work during the most productive time and to access an organization's documents from home, the suitability of having a workplace at home, the possibility to work from home in cases of sickness, and being able to take care family members (Nakrošienè et al. 2019). Empirical studies found several outcomes of working from home, such as increased job performance, improved job satisfaction, lesser turnover intentions, and reduced rates of stress (Vega et al. 2015; Contreras et al. 2020; Kossek et al. 2006; Fonner and Roloff 2010; Coenen and Kok 2014; Anderson et al. 2015). Work from home is carried out by various private and public sectors in Indonesia to work safely by adapting the concepts of telework, telecommuting, or flexible work. Working from home is a doubleedged sword (Schieman and Glavin 2017; Kim et al. 2019) that has a mixed effect on workers' work-life balance, well-being, and satisfaction. Working at home promotes job satisfaction (Cohen and Liani 2009; Chung 2018; Coenen and Kok 2014; Contreras et al. 2020). Many scholars described that teleworking or working from home can support worklife balance positively (Fisher et al. 2009; Ellis and Webster 1998; Fedáková and Ištoňová 2017) and negatively (Wessels et al. 2019; Novianti and Roz 2020). Working from home frequently results in a higher level of stress (Gajendran and Harrison 2007; Gálvez et al. 2020; Contreras et al. 2020; Fonner and Roloff 2010) and reduces stress if one has a flexible schedule (Azarbouyeh and Jalali Naini 2014; Kim et al. 2019). The conceptual framework of this research can be seen at Figure 1. Thus, working from home is hypothesized as follows:

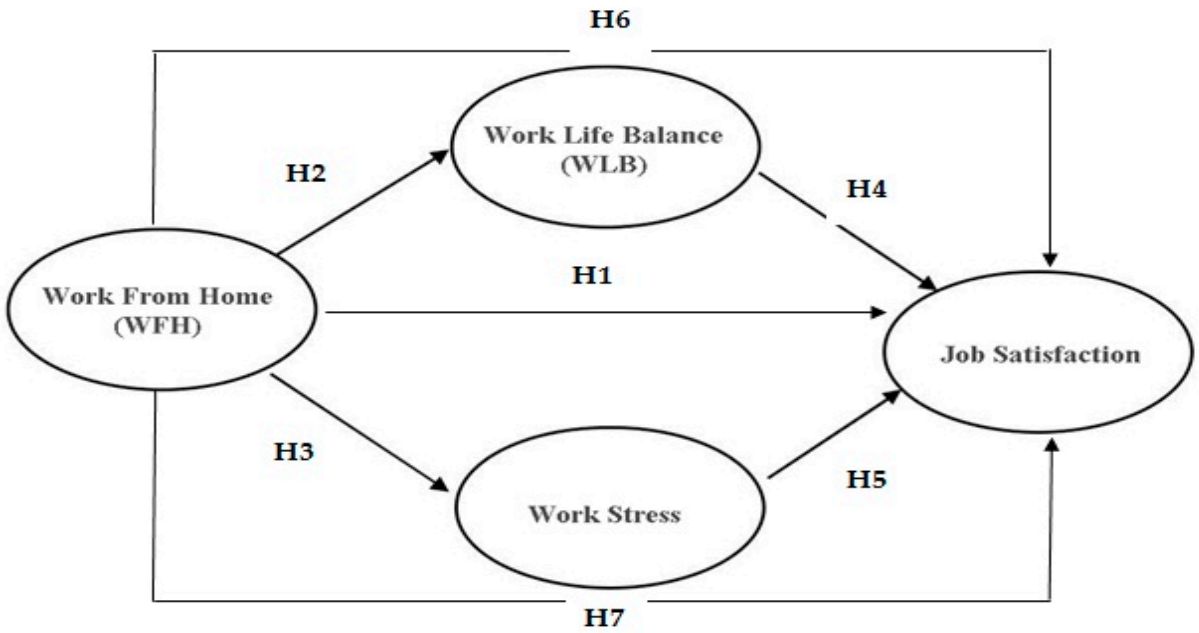

Figure 1. The conceptual model in this research.

Hypothesis 1 (H1). Working from home is positively related to job satisfaction.

Hypothesis 2 (H2). Working from home is positively related to work-life balance.

Hypothesis 3 (H3). Working from home is positively related to work stress.

\subsection{Work-Life Balance}

Work-life balance is described as achieving a balance between employees' family or personal life and work lives (Jyothi and Jyothi 2012). The concept of work-life balance is built on the idea that work life and personal life complement each other in presenting perfection in one's life. Furthermore, men and women employ flexible working in various ways, resulting in varied outcomes in terms of well-being and work-life balance (Chung 
and van der Lippe 2020; López-Igual and Rodríguez-Modroño 2020). Work-life balance can affect employee performance both positively and negatively. An imbalance between work and personal life can have an impact on low productivity and decreased performance of a person for an organization (Konrad and Mangel 2000; Cohen and Liani 2009). The individual will feel stressed when they lack the necessary resources to fulfill both work and family roles. The previous study shows that work-life balance was positively related to job satisfaction (Jackson and Fransman 2018). Thus, work-life balance is hypothesized as:

Hypothesis 4 (H4). Work-life balance is positively related to job satisfaction.

\subsection{Work Stress}

Work stress is a condition that affects the emotions, thought processes, and the thinking process. The gap between the demands of work with existing resources will cause work stress and make people feel more negative and dissatisfied. Work stress, in this current situation, may cause role ambiguity, overwork, role conflict, and time pressure during working from home, which can reduce job satisfaction (Kim et al. 2019). Work stress is another key predictor that affects job satisfaction and has a significant effect on job satisfaction (Hsu et al. 2019). The different results presented by Chao et al. (2015) show that work stress has a negative effect on job satisfaction. According to this result, work stress is hypothesized as follows:

Hypothesis $\mathbf{5}$ (H5). Work stress is negatively related to job satisfaction.

\subsection{Job Satisfaction}

The most widely cited of the many advantages of teleworking is improved job satisfaction (Virick et al. 2010). Job satisfaction has been defined and measured as both a global construct and a multi-dimensional dimension (Lund 2003) as a perceived correlation between what one wants from one's work and what one perceives it to offer (Locke 1970). Job satisfaction is described as a person's emotional state when something pleasant and beneficial has occurred as a result of their job appraisal or work experience. Workers experience a sense of fulfillment as a result of the features that aid and facilitate the achievement of their work's values (Clark 1996). When scholars and companies refer to teleworking or working from home, they seek to develop a new way of organizing work to support and increase the work-life balance of their employees (Belzunegui-Eraso and Erro-Garcés 2020). One possible determinant that will create innovation as a result of working from home is workers' satisfaction (Ellis and Webster 1998). This is taken as an effort to increase employee job satisfaction while working from home and has a mixed effect on workers' work-life balance, well-being, stress-related outcomes, and satisfaction (Roz 2019; Kim et al. 2019). Thus, it is proposed that

Hypothesis 6 (H6). Work-life balance mediates the effect of working from home on job satisfaction.

Hypothesis 7 (H7). Work stress mediates the effect of working from home on job satisfaction.

\section{Material and Methods}

The empirical analysis is based on a quantitative approach to understanding the link between the variables measured (work from home, work-life balance, work stress, and job satisfaction) through the research instruments during the first quarter of the COVID-19 pandemic in Indonesia. It uses both primary data (through an online questionnaire to collect demographic information and data about variables) and secondary data (academic articles, publications, and other resources). Participants of this study were Indonesian citizens who worked from home (full or shift, because not all sectors use full work from home). Although they originated from all parts across Indonesia, most participants came from Java Island, which is the center of the public and private sector in Indonesia. Questionnaires were distributed to 500 respondents, and 472 respondents completed and returned their online 
questionnaire. Convenience sampling was used with general criteria to filter participants, which is the work from home workers. The responses of the participants were collected on the basis of the 5-point Likert scale, one of the basic psychometric tools that is often used in the social sciences.

Work from home (WFH) measurements were adapted from Neufeld and Fang (2005) using 15 items consisting of five indicator telecommuting subscales (productivity, attitudinal factor, social factor, and situational factor based on resource and distraction). Work-life balance (WLB) was adapted from the work-life balance self-assessment scale that consists of 3 factors, namely, work interference with personal life (WIPL), personal life interference with work (PLIW), and work/personal life enhancement (WPLE) questionnaire by Fisher et al. (2009) that consist of 15 items. The work stress questionnaire developed by Lait and Wallace (2002) consists of 6 items. The job satisfaction questionnaire used in this study was adapted from Schriesheim and Tsui (1980) using 5 items (colleagues, supervisors, income, and overall job satisfaction). The survey items can be seen in Appendix A.

\section{Data Analysis and Results}

A total of 472 respondents participated in this study. Most participants were from Java Island, Bali, and Nusa Tenggara (90.4\%) or Sumatera and Kalimantan (7.1\%), and the rest were from Maluku, Sulawesi, or Papua. With regards to working from home, more than $71.9 \%$ had been doing so since 1-2 months ago. Concerning marital status, the majority of respondents indicated their marital status as married $(72.7 \%)$, and the remainder were unmarried $(27.3 \%)$. The socio-demographic characteristics of the participants in this study are summarized in Table 1.

Table 1. Demography of respondents.

\begin{tabular}{cccc}
\hline Particulars & Items & Frequency $(\boldsymbol{n}=\mathbf{4 7 2})$ & Percentage \\
\hline \multirow{2}{*}{ Gender } & Male & 303 & $64.2 \%$ \\
& Female & 169 & $35.8 \%$ \\
\hline \multirow{3}{*}{ Age (years) } & $20-25$ & 31 & $6.6 \%$ \\
& $26-30$ & 137 & $29 \%$ \\
& $31-35$ & 95 & $20.1 \%$ \\
& $36-40$ & 64 & $13.6 \%$ \\
Marital status & $>41$ & 145 & $30.7 \%$ \\
& Married & 343 & $72.7 \%$ \\
Education & Unmarried & 129 & $27.3 \%$ \\
\hline \multirow{2}{*}{ Tenure } & High school & 12 & $2.5 \%$ \\
& Diploma/bachelor's & 238 & $50.4 \%$ \\
& Master's/doctoral & 222 & $47 \%$ \\
\hline \multirow{2}{*}{ Length doing WFH } & $1-5$ years & 167 & $35.4 \%$ \\
& $6-10$ years & 99 & $21 \%$ \\
& $11-15$ years & 80 & $16.9 \%$ \\
& $16-20$ years & 37 & $7.8 \%$ \\
& $>20$ years & 89 & $18.8 \%$ \\
\hline \multirow{2}{*}{ Current employment } & Private company employees & 156 & $32.8 \%$ \\
& Government employees & 288 & $61.2 \%$ \\
& Others & 28 & $6 \%$ \\
\hline
\end{tabular}

Source: obtained from primary data.

For testing the psychometric of the data, we used SPSS Version 25 software from IBM to test the validity and reliability of the data instrument; meanwhile, we tested the model using SmartPLS version 3.02. Validity and reliability tests need to be performed to 
measure the extent to which the items used for the variables studied and are reliable. This study used three independent variables that are represented by work from home (WFH), work-life balance (WLB), and work stress (WS), and one dependent variable, namely, job satisfaction (JS), that consists of 41 items. After the validity test for the four variables was carried out, it turned out that several items could not be used in this study due to the calculated $r$-value of the item $<\mathrm{r}$ table; therefore, the researchers dropped the item as an effort to continue to the next stage. From 41 items, 11 items were dropped, and 30 items were ready to be used for the measurement model.

\subsection{Measurement Model}

We assessed the measurement of the research model by using three measures, namely, convergent validity, discriminant validity, and composite reliability (CR). Among all items tested, the basic outer loading value was $>0.5$, while for composite reliability, it was expected that the CR value was $>0.7$, and all variables were deemed to be valid, as presented in Table 2.

Table 2. Measurement model.

\begin{tabular}{|c|c|c|c|c|}
\hline Construct & Items & Loading & Cronbach's Alpha & CR \\
\hline Work from home & $\begin{array}{c}\text { WFH01 } \\
\text { WFH02 } \\
\text { WFH03 } \\
\text { WFH04 } \\
\text { WFH09 } \\
\text { WFH10 } \\
\text { WFH11 } \\
\text { WFH12 } \\
\text { WFH13 } \\
\text { WFH14 }\end{array}$ & $\begin{array}{l}0.753 \\
0.757 \\
0.726 \\
0.753 \\
0.665 \\
0.683 \\
0.749 \\
0.552 \\
0.549 \\
0.744\end{array}$ & 0.880 & 0.891 \\
\hline $\begin{array}{c}\text { Work-life } \\
\text { balance }\end{array}$ & $\begin{array}{l}\text { WLB01 } \\
\text { WLB02 } \\
\text { WLB03 } \\
\text { WLB04 } \\
\text { WLB05 } \\
\text { WLB07 } \\
\text { WLB09 } \\
\text { WLB10 } \\
\text { WLB11 }\end{array}$ & $\begin{array}{l}0.807 \\
0.813 \\
0.834 \\
0.778 \\
0.840 \\
0.769 \\
0.766 \\
0.772 \\
0.718\end{array}$ & 0.920 & 0.941 \\
\hline Work stress & $\begin{array}{l}\text { WS1 } \\
\text { WS2 } \\
\text { WS3 } \\
\text { WS4 } \\
\text { WS5 } \\
\text { WS6 }\end{array}$ & $\begin{array}{l}0.806 \\
0.813 \\
0.867 \\
0.889 \\
0.853 \\
0.887\end{array}$ & 0.925 & 0.903 \\
\hline Job satisfaction & $\begin{array}{l}\text { JS01 } \\
\text { JS02 } \\
\text { JS03 } \\
\text { JS04 } \\
\text { JS05 }\end{array}$ & $\begin{array}{l}0.835 \\
0.780 \\
0.758 \\
0.680 \\
0.877\end{array}$ & 0.849 & 0.937 \\
\hline
\end{tabular}

Source: PLS output.

The test was performed by comparing the $\sqrt{ }$ AVE on the correlation between latent variables. The rule was valid if the result stated that the $\sqrt{ }$ AVE was greater than the correlation between latent variables. It can be seen in Figure 2 that the AVE was greater than the correlation value between the latent variables, and therefore it was concluded that it fulfilled the discriminant validity test. The following are the test results stated in Table 3. 


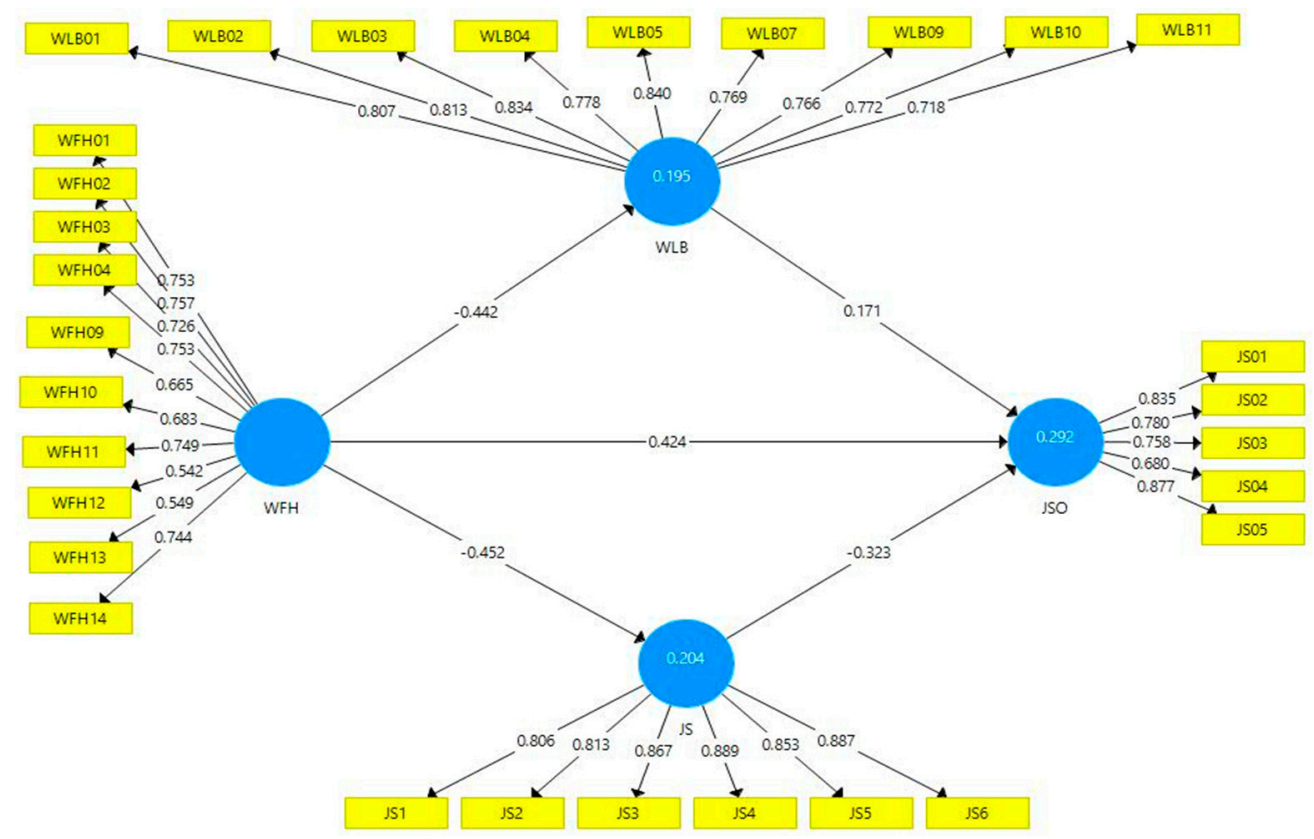

Figure 2. Measurement model (PLS algorithm).

Table 3. Discriminant validity.

\begin{tabular}{ccccccc}
\hline \multirow{2}{*}{ Variable } & \multirow{2}{*}{ AVE } & \multirow{2}{*}{ AVE } & \multicolumn{2}{c}{ Correlation Score among Latent Variables } \\
\cline { 4 - 7 } & & & WFH & WLB & WS & JS \\
\hline WFH & 0.623 & 0.789 & 0.789 & -0.442 & 0.737 & -0.254 \\
WLB & 0.728 & 0.853 & & 0.697 & -0.452 & 0.494 \\
WS & 0.585 & 0.764 & & & 0.853 & -0.389 \\
JS & 0.623 & 0.789 & & & & 0.789 \\
\hline
\end{tabular}

Source: PLS output.

\subsection{Structural Model}

After the estimated model met the criteria for convergent validity, discriminant validity, and composite reliability, the next step was to test the structural model. The structural model testing on PLS can be seen with goodness-of-fit. Each endogenous variable expressed with $R^{2}$ values such as the endogenous variable job satisfaction was $0.292(29.2 \%)$. Job satisfaction was found to be influenced by working from home, work-life balance, and work stress. Work stress was an endogenous variable of 0.204 , whereas $20.4 \%$ indicated that work stress was influenced by working from home. Work-life balance was an endogenous variable of 0.195 , whereas $19.5 \%$ indicates that work-life balance was influenced by working from home. In addition, the predictive relevance $\left(\mathrm{Q}^{2}\right)$ value can be calculated as follows:

$$
\begin{gathered}
\mathrm{Q}^{2}=1-\left(1-\mathrm{R}_{1}{ }^{2}\right)\left(1-\mathrm{R}_{2}{ }^{2}\right)\left(1-\mathrm{R}_{3}{ }^{2}\right) \\
\mathrm{Q}^{2}=1-(1-0.292)(1-0.204)(1-0.195) \\
\mathrm{Q}^{2}=1-0.479 \\
\mathrm{Q}^{2}=0.521
\end{gathered}
$$

This calculation showed a high value of 0.521 so that the model was feasible to be declared to have a predictive relevance value. The result of $52.1 \%$ illustrates the diversity of data that can be explained by the PLS model, or the information contained in the data can be explained by the model. Meanwhile, $47.9 \%$ was explained by other variables (not yet contained in the model) and error. 


\subsection{Hypotheses Testing}

In hypothesis testing by testing the significance of the path coefficient of partial least squares (PLS), the path coefficient showed the magnitude of the influence of one independent variable on the dependent variable. The path coefficient was obtained by testing using Smart-PLS software with the bootstrap method with 1000 subsamples. Furthermore, the criteria for a significance level of $95 \%$ with a standard error of $5 \%$ were $t>1.96$ and $p<0.05$. Table 4 below shows the results of the data analysis:

Table 4. Hypotheses testing.

\begin{tabular}{cccccc}
\hline Hypothesis & Relationship & Path Coefficient & t-Value & $p$-Value & Supported \\
\hline H1 & WFH $\rightarrow$ JS & 0.424 & 8.496 & 0.000 & Yes \\
H2 & WFH $\rightarrow$ WLB & -0.442 & 10.456 & 0.000 & Yes \\
H3 & WFH $\rightarrow$ WS & -0.452 & 9.642 & 0.000 & Yes \\
H4 & WLB $\rightarrow$ JS & 0.171 & 2.861 & 0.000 & Yes \\
H5 & WS $\rightarrow$ JS & -0.323 & 4.721 & 0.000 & Yes \\
H6 & WFH $\rightarrow$ WLB $\rightarrow$ JS & 0.146 & 3.926 & 0.000 & Yes \\
H7 & WFH $\rightarrow$ WS $\rightarrow$ JS & -0.075 & 2.729 & 0.000 & Yes \\
\hline
\end{tabular}

On the basis of the results of hypothesis testing that was carried out, the findings indicated that all proposed hypotheses were accepted because all path coefficients were significant. Working from home $(\beta=0.424, t=8.496>1.96, p<0.05)$ was found to have a significant and positive effect on job satisfaction. In terms of hypothesis 2 , working from home $(\beta=-0.442, \mathrm{t}=10.456>1.96, p<0.05)$ had a significant and negative effect on worklife balance. Likewise, working from home $(\beta=-0.452, \mathrm{t}=9.642>1.96, p<0.05)$ had a significant and negative effect on work stress. Meanwhile, work-life balance had a positive and significant effect on job satisfaction $(\beta=0.171, t=2.861>1.96, p<0.05)$. Furthermore, work stress $(\beta=-0.323, \mathrm{t}=4.721>1.96, p<0.05)$ had a significant and negative effect on job satisfaction. The mediating effect of the effect of work from home on job satisfaction was investigated by determining the interaction effect of work-life balance and job stress. The findings revealed that work-life balance can mediate the effect of working from home on job satisfaction $(\beta=0.146, t=3.926>1.96, p<0.05)$. Furthermore, work stress is also able to mediate the effect of working from home on job satisfaction $(\beta=-0.075, t=2.729>$ $1.96, p<0.05)$. All hypotheses tested in this research were all accepted.

\section{Discussion}

The first construct of this research was teleworking or working from home related to organizational outcomes such as job satisfaction. The hypotheses for this construct were divided into three sub-hypotheses that showed its relationship to other variables observed in this study. On the basis of the analysis result, we can confirm that working from home has a significant and negative effect on work-life balance. This finding indicates that working from home leads to a decreased level of job satisfaction. This condition is the result of the working from home policy released by the Indonesian government that has been implemented for the first time in Indonesia, and thus adaptation is still needed for this new working style. When the work from home policy was applied during the pandemic due to it being perceived to be the best option for Indonesian workers, workers who were could not access good IT infrastructure needed to evaluate this new working style, especially for the type of work that requires full support of ICTs. This finding is similar to that of previous studies (Golden and Eddleston 2020; Novianti and Roz 2020; Gajendran and Harrison 2007; Virick et al. 2010).

The second hypothesis confirmed that working from home has a significant and negative effect on work-life balance. Employees are not able to divide their time between work and personal life because they are still used to having fixed working hours. Creating boundaries between work and personal life to create a work-life balance condition is not an easy thing, especially in the pandemic situation that has many restriction policies. A previous study notes that telecommuting work in the digital workplace may offer a strategy 
for creating flexibility that opens workers' creativity as long as the work-life balance strategies are stretched and implemented well by the workers through organizational support (Lee and Sirgy 2019). Therefore, it is noted that Indonesia needs more time in terms of the nation-wide policy for working from home, with the correct strategies in this digital work setting, innovation could be boosted. The negative consequences may impact on personal well-being, but in terms of productivity and innovation, the opportunity is still wide open, acknowledging the fact that Indonesia is a collective society where a good pace of teamwork setting in the digital space may open up creative ideas (Valcour and Hunter 2017).

The third hypothesis was that working from home has a significant and negative effect on work stress. The present pandemic forces workers to do extra work, even working overtime because they have to be able to finish the job they were meant to do. Social isolation leads to employees being disconnected from their working environment and triggers work stress. This result is somehow congruent with the study of Gajendran and Harrison (2007), wherein the authors found that the more intense the job load through a telecommuting setting, the more stress was placed on the workers. The study found that in the early stages of the pandemic, the workers were still adapting and the employees were still setting up the correct pace of the work from home policy, wherein the stress levels were still lower; this may prove that in adaptation to the new work setting, the workers may have felt stress but at the same time, the closeness the family members may have reduced their stress levels (Hilbrecht et al. 2008, 2013).

The fourth hypotheses result confirmed that work-life balance has a positive and significant effect on job satisfaction. Employees have the flexibility and autonomy in balancing their work and personal life and tend to increase their job satisfaction. This result is somewhat congruent with the study of Song and Gao (2019), wherein non-fixed workers had more job satisfaction when the organization gave them the flexibility to work from home, as it was reported in the demographic information that the majority of the respondents were classified as being in the early stage of work (tenure less than 5 years) as in the organizational behavior literature they are still regarded as adapting to the work pace, and in the early stages of their career, people tend to be flexible within tight work deadlines, which may be related to the workload of the non-fixed worker.

The fifth hypothesis was that work stress has a significant and negative effect on job satisfaction. Within the context of a normal work setting, work stress may affect job satisfaction; however, in this study where the workers were forced to work from home, work stress also affected job satisfaction but in a negative direction. Stewart and Barling (1996) pointed out that subjective work stress may negatively affect job performance, in turn decreasing job satisfaction. This means in this early work from home setting, an unclear direction of what needs to be done can somehow make the workers stressed and in turn not affect their present job satisfaction.

The last outcome of this study dealt with the relationship between working from home and job satisfaction mediated by work-life balance (sixth hypothesis) and the relationship between working from home and job satisfaction mediated by work stress (seventh hypothesis). This study found that work-life balance can mediate the effect of work from home on job satisfaction. With regards to the intention of increasing job satisfaction, the study by Fonner and Roloff (2010) found that worker satisfaction in telecommuting work is attained, and it shows that the work-life balance and work stress also mediated this relationship. In light of triggering innovation in these innovative workplaces such as in this digital setting, Oh and Choi (2020) point out that comfort is one of the determinants in creating a high-performance team, and our study confirms that in the early stages of working from home, the worker's satisfaction is maintained as it is balanced with the fulfillment of work-life balance. 


\section{Conclusions}

This study initially focused on seeking the determinant of work-life balance in the early pandemic wherein the unclear direction of working from home in Indonesia was not regulated well, neither from the government nor the policy itself within the organization. The work-life balance concept is rarely discussed in the collectivist setting. In this study, as the workers became close with their family, the concept of work life balance was received as a positive sign, which in some areas could increase their job satisfaction, while in the other side, work stress needs to be paid attention to. Work stress can affect job satisfaction in a normal work setting; however, in this study, where workers were forced to work from home, work stress had a negative impact on job satisfaction. This study sheds light on the fact that even though it is uncommon for Indonesian workers to work in the telecommuting setting, hopes for increasing productivity are still open when it is accompanied by the right policy. The study reveals that working from home as the new climate of working for Indonesian workers can maintain their job satisfaction, and it is expected that they commit to their work and fulfill their task accomplishment.

The paper provides several practical implications for the use of the working from home policy in an Indonesian context, especially in terms of the COVID-19 pandemic. The leaders of organizations need to pay attention to their employees' job satisfaction during their working from home. It is undeniable that working from home can interfere with employees' work life balance and work stress. In addition, it is also necessary to pay attention to the workload that must be completed, considering that working in remote conditions has obstacles such as lack of IT support and other jobs that result in a decrease in job satisfaction.

The paper has limitations, despite using online questionnaires that were distributed through personal networks that are able to reach all respondents from all over Indonesia, the incomplete responses were not analyzed due to the limited time in following them up to fill the survey. Further detailed instrument adoption and translation need to be carried out using the back-translation method to provide questions that have the same perception for individuals across Indonesia.

Future research needs to re-conceptualize the boundaries of telecommuting work and working from home, as it is visually the same, but in some areas, non-digital workers are not familiar with the concepts of telecommuting work settings. Where possible, dyadic research is encouraged so that the conceptualization of work from home from the perspectives of supervisor or manager can be operationalized.

Author Contributions: Conceptualization, D.W.I.; methodology, D.W.I.; software, K.R.; validation, K.R.; formal analysis, D.W.I.; investigation, D.W.I.; resources, K.R.N.; data curation, D.W.I.; writing-original draft preparation, D.W.I.; writing—review and editing, K.R.N.; visualization, D.W.I.; supervision, D.W.I.; project administration, K.R.N. All authors have read and agreed to the published version of the manuscript.

Funding: This research received no external funding.

Conflicts of Interest: The authors declare no conflict of interest.

\section{Appendix A. (Survey Items)}

Work From Home Productivity (adapted from Neufeld and Fang (2005))

I am very productive while working from home.

I feel that the quality of the work I do during working from home is better.

Working from home is personally beneficial for me at work.

Working from home motivates me to work better.

I have sufficient technical knowledge in completing work during working from home. I have sufficient authority in carrying out work during working from home.

I have clear work targets when working from home.

My boss is concerned about my well-being during working from home. 
I receive technical assistance from my workplace in completing work during working from home.

I can concentrate on getting work done even when there are distractions from family members during working from home.

Work Life Balance (adapted from Fisher et al. (2009))

My personal life suffers because of work.

My job makes my personal life difficult.

I neglect personal needs because of work.

I put off enjoying my personal time just to work during working from home.

I put personal needs second because of work.

I struggle to separate work and non-work.

Most of the time, I prefer work from home rather than engage in personal interests.

I'm too tired to work from home.

My work suffers because of my personal life/interests during working from home.

Work Stress (Lait and Wallace (2002))

I am discouraged about my work.

I feel many things are beyond my control and ability while working from home.

I feel overwhelmed by completing work during working from home.

I feel like giving up on work during working from home.

I feel unable to get out from my work during working from home.

I feel frustrated with my work from home job.

Job Satisfaction (Schriesheim and Tsui (1980))

I am satisfied with my current job.

I am satisfied with my current co-workers.

I am satisfied and feel happy with my current boss.

I am satisfied with my current salary.

Overall, I am satisfied with my current job.

\section{References}

Ammons, Samantha K., and William T. Markham. 2004. Working at Hdome: Experiences of Skilled White Collar Workers. Sociological Spectrum 24: 191-238. [CrossRef]

Anderson, Amanda J., Seth A. Kaplan, and Ronald P. Vega. 2015. The Impact of Telework on Emotional Experience: When, and for Whom, Does Telework Improve Daily Affective Well-Being? European Journal of Work and Organizational Psychology 24: 882-97. [CrossRef]

Azarbouyeh, Amir, and Seyed Gholamreza Jalali Naini. 2014. A Study on the Effect of Teleworking on Quality of Work Life. Management Science Letters 4: 1063-68. [CrossRef]

Baruch, Yehuda. 2000. Baruch-2000-New Technology, Work and Employment Qualis A1 Muito Importante. New Technology, Work and Employment (Print) 15: 34-49. [CrossRef]

Baruch, Yehuda. 2001. The Status of Research on Teleworking and an Agenda for Future Research. International Journal of Management Reviews 3: 113-29. [CrossRef]

Belzunegui-Eraso, Angel, and Amaya Erro-Garcés. 2020. Teleworking in the Context of the Covid-19 Crisis. Sustainability 12: 3662. [CrossRef]

Bentley, Tim Andrew, Stephen T. T. Teo, Laurie McLeod, Felix Tan, Rachelle Bosua, and Marianne Gloet. 2016. The Role of Organisational Support in Teleworker Wellbeing: A Socio-Technical Systems Approach. Applied Ergonomics 52: 207-15. [CrossRef]

Chao, Ming Che, Rong Chang Jou, Cing Chu Liao, and Chung Wei Kuo. 2015. Workplace Stress, Job Satisfaction, Job Performance, and Turnover Intention of Health Care Workers in Rural Taiwan. Asia-Pacific Journal of Public Health 27: NP1827-NP1836. [CrossRef] [PubMed]

Chung, Heejung. 2018. Future of Work and Flexible Working in Estonia: The Case of Employee-Friendly Flexibility. Tallin: Arenguseire Keskus, p. 42.

Chung, Heejung, and Tanja van der Lippe. 2020. Flexible Working, Work-Life Balance, and Gender Equality: Introduction. Social Indicators Research 151: 365-81. [CrossRef]

Clark, Andrew E. 1996. Job Satisfaction in Britain. British Journal of Industrial Relations 34: 189-217. [CrossRef]

Coenen, Marja, and Robert A. W. Kok. 2014. Workplace Flexibility and New Product Development Performance: The Role of Telework and Flexible Work Schedules. European Management Journal 32: 564-76. [CrossRef]

Cohen, Aaron, and Efrat Liani. 2009. Work-Family Conflict among Female Employees in Israeli Hospitals. Personnel Review 38: $124-41$. [CrossRef] 
Contreras, Francoise, Elif Baykal, and Ghulam Abid. 2020. E-Leadership and Teleworking in Times of COVID-19 and Beyond: What We Know and Where Do We Go. Frontiers in Psychology 11: 3484. [CrossRef]

Di Martino, Vittorio, and Linda Wirth. 1990. Telework: A New Way of Working and Living. International Labour Review 129: 529-54.

Ellis, Selwyn T., and Robert L. Webster. 1998. IS Managers' Innovation toward Telecommuting: A Structural Equation Model. Proceedings of the Hawaii International Conference on System Sciences 4: 161-68. [CrossRef]

Fedáková, Denisa, and Lucia Ištoňová. 2017. Slovak IT-Employees and New Ways of Working: Impact on Work-Family Borders and Work-Family Balance. Československá Psychologie (Czechoslovak Psychology) LXI: 68-83.

Fisher, Gwenith G., Carrie A. Bulger, and Carlla S. Smith. 2009. Beyond Work and Family: A Measure of Work/Nonwork Interference and Enhancement. Journal of Occupational Health Psychology 14: 441-56. [CrossRef] [PubMed]

Fonner, Kathryn L., and Michael E. Roloff. 2010. Why Teleworkers Are More Satisfied with Their Jobs than Are Office-Based Workers: When Less Contact Is Beneficial. Journal of Applied Communication Research 38: 336-61. [CrossRef]

Gajendran, Ravi S., and David A. Harrison. 2007. The Good, the Bad, and the Unknown About Telecommuting: Meta-Analysis of Psychological Mediators and Individual Consequences. Journal of Applied Psychology 92: 1524-41. [CrossRef]

Gálvez, Ana, Francisco Tirado, and Jose M. Alcaraz. 2020. ‘Oh! Teleworking!' Regimes of Engagement and the Lived Experience of Female Spanish Teleworkers. Business Ethics 29: 180-92. [CrossRef]

Golden, Timothy D., and Kimberly A. Eddleston. 2020. Is There a Price Telecommuters Pay? Examining the Relationship between Telecommuting and Objective Career Success. Journal of Vocational Behavior 116: 103348. [CrossRef]

Hilbrecht, Margo, Susan M. Shaw, Laura C. Johnson, and Jean Andrey. 2008. 'I'm Home for the Kids': Contradictory Implications for Work-Life Balance of Teleworking Mothers. Gender Work and Organization 15: 454-76. [CrossRef]

Hilbrecht, Margo, Susan M. Shaw, Laura C. Johnson, and Jean Andrey. 2013. Remixing Work, Family and Leisure: Teleworkers' Experiences of Everyday Life. New Technology, Work and Employment 28: 130-44. [CrossRef]

Hsu, Ya Yuan, Chyi Huey Bai, Chien Ming Yang, Ya Chuan Huang, Tzu Ting Lin, and Chih Hung Lin. 2019. Long Hours' Effects on Work-Life Balance and Satisfaction. BioMed Research International. [CrossRef]

Jackson, Leon T. B., and Edwina I. Fransman. 2018. Flexi Work, Financial Well-Being, Work-Life Balance and Their Effects on Subjective Experiences of Productivity and Job Satisfaction of Females in an Institution of Higher Learning. South African Journal of Economic and Management Sciences 21: 1-13. [CrossRef]

Johnson, Laura C., Jean Andrey, and Susan M. Shaw. 2007. Mr. Dithers Comes to Dinner: Telework and the Merging of Women's Work and Home Domains in Canada. Gender, Place and Culture 14: 141-61. [CrossRef]

Jyothi, Sree V., and P. Jyothi. 2012. Assessing Work-Life Balance: From Emotional Intelligence and Role Efficacy of Career Women. Advances in Management 5: 332.

Kazekami, Sachiko. 2020. Mechanisms to Improve Labor Productivity by Performing Telework. Telecommunications Policy 44 : 101868. [CrossRef]

Kim, Jaeseung, Julia R. Henly, Lonnie M. Golden, and Susan J. Lambert. 2019. Workplace Flexibility and Worker Well-Being by Gender. Journal of Marriage and Family. [CrossRef]

Konrad, Alison M., and Robert Mangel. 2000. The Impact of Work-Life Programs on Firm Productivity. Strategic Management Journal 21: 123. [CrossRef]

Kossek, Ellen Ernst, Brenda A. Lautsch, and Susan C. Eaton. 2006. Telecommuting, Control, and Boundary Management: Correlates of Policy Use and Practice, Job Control, and Work-Family Effectiveness. Journal of Vocational Behavior 68: 347-67. [CrossRef]

Kramer, Amit, and Karen Z. Kramer. 2020. The Potential Impact of the Covid-19 Pandemic on Occupational Status, Work from Home, and Occupational Mobility. Journal of Vocational Behavior, 103442. [CrossRef]

Lait, Jana, and Jean E. Wallace. 2002. Stress at Work: A Study of Organizational-Professional Conflict and Unmet Expectations. Relations Industrielles 57: 463-90. [CrossRef]

Lee, D. J., and M. J. Sirgy. 2019. Work-Life Balance in the Digital Workplace: The Impact of Schedule Flexibility and Telecommuting on Work-Life Balance and Overall Life Satisfaction. In Thriving in Digital Workspaces. Cham: Springer.

Liu, Huei Ling, and Ven hwei Lo. 2018. An Integrated Model of Workload, Autonomy, Burnout, Job Satisfaction, and Turnover Intention among Taiwanese Reporters. Asian Journal of Communication 28: 153-69. [CrossRef]

Locke, Edwin A. 1970. Job Satisfaction and Job Performance: A Theoretical Analysis. Organizational Behavior E Human Performance 5: 484-500.

López-Igual, Purificación, and Paula Rodríguez-Modroño. 2020. Who Is Teleworking and Where from? Exploring the Main Determinants of Telework in Europe. Sustainability 12: 8797. [CrossRef]

Lund, Daulatram B. 2003. Organizational Culture and Job Satisfaction. Journal of Business E Industrial Marketing 18: $219-36$.

Martin, Brittany Harker, and Rhiannon MacDonnell. 2012. Is Telework Effective for Organizations?: A Meta-Analysis of Empirical Research on Perceptions of Telework and Organizational Outcomes. Management Research Review 35: 602-16. [CrossRef]

Marx, Charlotte K., Mareike Reimann, and Martin Diewald. 2021. Do Work-Life Measures Really Matter? The Impact of Flexible Working Hours and Home-Based Teleworking in Preventing Voluntary Employee Exits. Social Sciences 10: 9. [CrossRef]

Nakrošienè, Audronè, Ilona Bučiūnienè, and Bernadeta Goštautaitè. 2019. Working from Home: Characteristics and Outcomes of Telework. International Journal of Manpower 40: 87-101. [CrossRef]

Neirotti, Paolo, Emilio Paolucci, and Elisabetta Raguseo. 2013. Mapping the Antecedents of Telework Diffusion: Firm-Level Evidence from Italy. New Technology, Work and Employment 28: 16-36. [CrossRef] 
Neufeld, Derrick J., and Yulin Fang. 2005. Individual, Social and Situational Determinants of Telecommuter Productivity. Information and Management 42: 1037-49. [CrossRef]

Nilles, Jack M. 1997. Telework: Enabling Distributed Organizations: Implications for It Managers. Information Systems Management 14: 7-14. [CrossRef]

Novianti, Khusnul Rofida, and Kenny Roz. 2020. Teleworking and Workload Balance on Job Satisfaction: Indonesian Public Sector Workers During Covid-19 Pandemic. APMBA (Asia Pacific Management and Business Application) 1: 8997. [CrossRef]

Oh, Minjeong, and Sungyong Choi. 2020. The Competence of Project Team Members and Success Factors with Open Innovation. Journal of Open Innovation: Technology, Market, and Complexity 6: 51. [CrossRef]

Raišiene, Agota Giedre, Violeta Rapuano, Kristina Varkulevičiute, and Katarína Stachová. 2020. Working from Home-Who Is Happy? A Survey of Lithuania's Employees during the COVID-19 Quarantine Period. Sustainability 12: 5332. [CrossRef]

Roz, Kenny. 2019. Job Satisfaction as a Mediation of Transformational Leadership Style on Employee Performance in the Food Industry in Malang City. International Journal of Economics, Business and Accounting Research (IJEBAR) 3: 47-58. [CrossRef]

Schieman, Scott, and Paul Glavin. 2017. Ironic Flexibility: When Normative Role Blurring Undermines the Benefits of Schedule Control. Sociological Quarterly 58: 51-71. [CrossRef]

Schriesheim, Chester, and Anne S. Tsui. 1980. Development and Validation of a Short Satisfaction Instrument for Use in Survey Feedback Interventions. Western Academy of Management Meeting 1980: 115-17.

Song, Younghwan, and Jia Gao. 2019. Does Telework Stress Employees Out? A Study on Working at Home and Subjective Well-Being for Wage/Salary Workers. Journal of Happiness Studies. [CrossRef]

Stewart, Wendy, and Julian Barling. 1996. Daily Work Stress, Mood and Interpersonal Job Performance: A Mediational Model. Work and Stress 10: 336-51. [CrossRef]

Valcour, P. Monique, and Larry W. Hunter. 2017. Technology, Organizations, and Work-Life Integration. In Work and Life Integration: Organizational, Cultural, and Individual Perspectives. Mahwah: Lawrence Erlbaum Associates, pp. 61-84.

van Meel, Juriaan. 2011. The Origins of New Ways of Working: Office Concepts in the 1970s. Facilities 29: 357-67. [CrossRef]

Vega, Ronald P., Amanda J. Anderson, and Seth A. Kaplan. 2015. A Within-Person Examination of the Effects of Telework. Journal of Business and Psychology 30: 313-23. [CrossRef]

Virick, Meghna, Nancy DaSilva, and Kristi Arrington. 2010. Moderators of the Curvilinear Relation between Extent of Telecommuting and Job and Life Satisfaction: The Role of Performance Outcome Orientation and Worker Type. Human Relations 63: 137-54. [CrossRef]

Wessels, Christina, Michaéla C. Schippers, Sebastian Stegmann, Arnold B. Bakker, Peter J. van Baalen, and Karin I. Proper. 2019. Fostering Flexibility in the New World of Work: A Model of Time-Spatial Job Crafting. Frontiers in Psychology 10: 1-13. [CrossRef]

Wojčák, Emil, and Matúš Baráth. 2017. National Culture and Application of Telework in Europe. European Journal of Business Science and Technology 3: 65-74. [CrossRef] 